\title{
Assessing Potentially Inappropriate Medications in Hospitalized Geriatric Patients in 2 Hospital in Jakarta using STOPP START criteria
}

\author{
Daniek Viviandhari", Nora Wulandari, Numlil Khaira Rusdi, Nur Rahmi, Nurul Hildayana, Noni Sri Susi \\ Faniroh \\ Faculty of Pharmacy and Science, Universitas Muhammadiyah Prof. Dr. HAMKA \\ Submitted: 22-08-2019 Revised: 11-11-2019 Accepted: 26-03-2020 \\ Korespondensi : Daniek Viviandhari : Email : daniek.viviandhari@uhamka.ac.id
}

\begin{abstract}
Geriatric patients have more comorbidities and often receive polypharmacy prescriptions. The prevalence of inappropriate drug use in geriatric patients is in the range of $11.5 \%-62.5 \%$. The consequence of polypharmacy is Adverse Drug Reactions (ADR). An effort to reduce the occurrence of medication errors in geriatric patients is the STOPP and START criteria. This study aimed to identify PIMs (Potentially Inappropriate Medications) and PPO (Potentially Prescribing Omission) in geriatric patients according to STOPP / START criteria at Gatot Soebroto Army Hospital and the Jakarta Cempaka Putih Islamic Hospital. This study used a descriptive-analytical method with a cross-sectional design and a prospective data collection method based on analysis of medical records, inpatient installation, and pharmacy installation at Gatot Soebroto Army Hospital in Jakarta on October 2017 and Jakarta Cempaka Putih Islamic Hospital in January 2019. The tool used to collect data in this research was the STOPP START toolkit supporting medication review version 1 2016. The results show that of 85 hospitalized geriatric patients at Gatot Soebroto Army Hospital with the use of 579 drugs, PIMs were present in $8.24 \%$ of patients and the prevalence of PPO was 5.88\%. Meanwhile, out of 124 hospitalized geriatric patients in Jakarta Cempaka Putih Islamic Hospital with the use of 945 drugs, PIMs were present in $35.48 \%$ of patients and the prevalence of PPO was $6.45 \%$. Polypharmacy found to be an independent predictor for PIMs incident.
\end{abstract}

Keywords: geriatrics; PIMs; PPO; STOPP/START criteria

\section{INTRODUCTION}

There is an increase in the number of population of persons age 65 years and older nowadays ${ }^{1}$ It has been estimated that the proportion of the world's population over 60 years will nearly double from $12 \%$ in 2015 to $22 \%$ in $2050^{2}$. Geriatric patients are elderly patients with multiple diseases and/or disorders due to decreased organ, psychological, social, economic and environmental functions that require integrated health services with a multidisciplinary approach ${ }^{3}$. In Indonesia, the morbidity rate for the elderly was $28.62 \%$ in 2015, meaning that out of every 100 elderly people there were around 28 people who were ill'.

Geriatric-related physiological changes cause pharmacokinetic and pharmacodynamic changes in drugs in geriatric patients. Geriatric patients have more comorbidities and often receive polypharmacy prescriptions. Polypharmacy refers to the use of several drugs, five or more types. Recently, polypharmacy is used to describe PIP (Potentially Inappropriate Prescribing) or the use of drugs that are not quite right. The prevalence of inappropriate use of drugs in geriatric patients is in the range of $11.5 \%$ $62.5 \%$. The consequence of polypharmacy is Adverse Drug Reactions 5 .

One effort to reduce the occurrence of medication errors in geriatric patients involves the use of a standard list of drugs classified according to the risks and benefits generated, aimed at guiding doctors when choosing treatment for patients, including the Beers and STOPP and START criteria methods. The STOPP criteria (screening tool for geriatric prescription) and START (screening tool to remind doctors of appropriate prescription) were created in 2003 to overcome possible deficiencies of the Beers criteria. These criteria comprise potentially unsuitable drugs Potentially Inappropriate Medications (PIMs) explained by STOPP, and potential omissions 
for prescription Potential Prescribing Omissions (PPO), explained by START. This START method is intended to increase treatment success in geriatric patients ${ }^{6,7}$.

In one study, it was found that $22 \%$ of geriatric patients met the STOPP / START criteria $^{8}$. Another study conducted in Turkey found $14.8 \%$ of inappropriate drug use according to STOPP criteria ${ }^{9}$. Research data in Indonesia include research conducted in Yogyakarta. From this study, 17\% of patients with chronic kidney disease obtained an average of one PIMs, while $38.9 \%$ of patients with osteoarthritis obtained an average of one PIMs ${ }^{10,11}$

The results of the identification of PIMs with the STOPP and START screening tool have not been well documented in Indonesia, especially in hospitals in Jakarta. The researcher found the necessary to assess PIMs and PPO based on STOPP and START criteria to reduce the incidence of Adverse Drug Reactions (ADR).

The increasing number of geriatrics both in Indonesia and in the world will increase the need for health. Previous research data states that there is an increase in ADR in the elderly, so the use of drugs in the elderly should continue to be evaluated to improve patient clinical outcomes. This evaluation is expected to be a standard or guideline for hospitals in the treatment of geriatric patients.

The objective of this research is to obtain information about the patient characteristics, find out and identify Potentially Inappropriate Medications (PIMs) and Potentially Prescribing Omission (PPO) in geriatric patients according to STOPP / START criteria at Gatot Soebroto Army Hospital and Jakarta Cempaka Putih Islamic Hospital, and also to find the correlation between patient characteristics and PIMs. The research used the tools which is already used worldwide. The differences between this research and another similar researches that had been conducted in Jakarta were the prospective method and the greater number of samples. The data obtained is expected to be used as guidelines/treatment guidelines for geriatric patients in the hospital.

\section{METHODS \\ Materials}

The tool used to collect data in this research was the STOPP START toolkit supporting medication review version 12016.

\section{Methods}

This research was descriptive with prospective data collection methods using STOPP START toolkit supporting medication review version 1 2016. The population of this study is all geriatric inpatients at Gatot Soebroto Army Hospital in October 2017 and Jakarta Cempaka Putih Islamic Hospital January 2019 period. The reason for using 2 different time periods is inadequate data in 2017 and further research can only be carried out in early 2019. The samples of this study were all geriatric inpatient at Gatot Soebroto Army Hospital in October 2017 and Jakarta Cempaka Putih Islamic Hospital in January 2019 that met the following inclusion criteria and exclusion criteria:

Inclusion criteria: patients aged $\geq 60$ years, patients had complete medical record data, including age, sex, diagnosis, drug use, and laboratory data (hematological examination such as, hematocrit, hemoglobin, erythrocytes, and leukocytes; examination of electrolyte levels, glucose levels, blood gas analysis, and uric acid levels; examination of kidney function such as creatinine and creatinine clearance urinalysis including, $\mathrm{pH}$, urine color; liver function tests; lipid examination such as, Low Density Lipoprotein (LDL), High Density Lipoprotein (HDL), and triglycerides).

Exclusion criteria: geriatric patients were hospitalized at the Gatot Soebroto Army Hospital and Jakarta Cempaka Putih Islamic Hospital which had not been discharged after the research schedule and patients who had died.

The research proposal was submitted to the Ethics Committee of Faculty of Medicine, University of Indonesia. This study had received the Ethical Approval test and 
was declared to pass the study ethics study with the protocol number 18-09-1142. The patient screening was done after the research permit was obtained. Research procedure: submission of a request for a research permit to the hospital and ethical approval (ethical review) to the ethics committee. The minimum sample size was not specified, the sampling method used was total sampling, that was all respondents who are meet the inclusion criteria. Data were obtained from medical records, inpatient installation, and pharmacy installation. The study took place prospectively for 1 month. Screening of the accuracy of treatment prescribed for inpatient geriatric patients. The data obtained was then recapitulated for data processing and analysis.

\section{Data Analysis}

Data were analyzed descriptively to obtain a frequency distribution as well as the proportion of the variable of the study. The variable was patient characteristic. Data were also assessed for PIMs and PPO. STOPP START toolkit supporting medication review version 12016 contains a list of drugs which consider into the STOPP category (hereinafter referred to as PIMs), which means the use of these drugs on geriatrics needs to be stopped. Besides, the toolkit also contains a list of drugs that needs to be initiated (hereinafter referred to as PPO), which consider into the START category, which means a continuation of recommendations from drugs that were previously recommended to be stopped due to the PIMs incidence from STOPP.

From the samples obtained, it will be determined the proportion of the samples identified to have PIMs as well as what drugs have the most PIMs. Then from each drug that is included in STOPP, also listed alternative treatment (START) recommendation. Pearson's chi-squared test was performed to determine the correlation between patient characteristic and PIMs. Statistical significance was set at $p<0.05$. All statistical analysis was performed using the Statistical Package for
Social Sciences software for Windows version 16.0 .

\section{RESULTS AND DISCUSSION}

As many as 85 patients were selected as respondents from Gatot Soebroto Army Hospital during October 2017 and 124 patients from Jakarta Cempaka Putih Islamic Hospital during January 2019.

\section{Patient characteristics}

Distribution of patients based on patient characteristics was shown in table I. Female was the major respondents $52.94 \%$ at Gatot Soebroto Army Hospital and 59.68\% at Jakarta Cempaka Putih Islamic Hospital). This result is related to the data of the elderly population in Indonesia in 2017 which states that the number of elderly women is higher at $9.53 \%$ compared to elderly men at $8.54 \%{ }^{4}$. The majority of respondents aged 60-74 years (74.12\% at Gatot Soebroto Army Hospital and $72.58 \%$ at Jakarta Cempaka Putih Islamic Hospital). According to a report, the number of elderly is growing fast. In 2017, the population aged 60-79 is higher than the population aged $>80$ years. The number of older people over 80 years has also increased. World population aged 80 years or more is expected to increase 3-fold between 2017 and 2050, increasing from 137 million to 425 million ${ }^{12}$.

The respondents mostly used 5-10 medicines at Gatot Soebroto Army Hospital $(67.06 \%)$ as well as at Jakarta Cempaka Putih Islamic Hospital (65.32\%). Pharmacokinetic changes will occur in line with ageing. Therefore it is necessary to adjust the dose to avoid the occurrence of ADR. The risk of ADR events generally arises due to polypharmacy, especially in geriatrics ${ }^{13}$ and this risk will increase with age, comorbidity, and the number of drugs consumed ${ }^{14}$. Other risk factors associated with polypharmacy are DRP, such as unwanted side effects (ADEs), low compliance with drug use, drug-drug interactions, drug-disease interactions, and high risk of the geriatric syndrome ${ }^{15}$. 
Table I. Patient Characteristic

\begin{tabular}{|c|c|c|c|c|}
\hline \multirow[t]{3}{*}{ Location } & & Characteristic & Frequency & $\%$ \\
\hline & \multirow{2}{*}{ Sex } & Male & 40 & 47.06 \\
\hline & & Female & 45 & 52.94 \\
\hline Gatot & \multirow{3}{*}{ Age $^{*}$} & $60-74$ years & 63 & 74.12 \\
\hline Soebroto & & $75-90$ years & 21 & 24.71 \\
\hline Army & & $>90$ years & 1 & 1.17 \\
\hline \multirow[t]{3}{*}{ Hospital } & \multirow{3}{*}{$\begin{array}{l}\text { The number of } \\
\text { medicines }\end{array}$} & $1-4$ & 17 & 21.18 \\
\hline & & $5-10$ & 58 & 67.06 \\
\hline & & $>10$ & 10 & 11.76 \\
\hline \multirow[t]{2}{*}{ Total } & \multirow{4}{*}{ Sex } & & 85 & 100 \\
\hline & & Male & 50 & 40.32 \\
\hline Jakarta & & Female & 74 & 59.68 \\
\hline Cempaka & & 60-74 years & 90 & 72.58 \\
\hline Putih Islamic & Age $^{*}$ & $75-90$ years & 34 & 27.42 \\
\hline \multirow[t]{4}{*}{ Hospital } & \multirow{4}{*}{$\begin{array}{l}\text { The number of } \\
\text { medicines }\end{array}$} & $>90$ years & 0 & 0.00 \\
\hline & & $1-4$ & 27 & 21.78 \\
\hline & & $5-10$ & 81 & 65.32 \\
\hline & & $>10$ & 16 & 12.90 \\
\hline Total & & & 124 & 100 \\
\hline
\end{tabular}

${ }^{*}$ Age is based on WHO classification

Table II. PIMs and PPO

\begin{tabular}{lccc}
\hline Location & Number of & patients & $\%$ \\
\hline Gatot Soebroto Army Hospital & PIMs & 7 & 8.24 \\
& PPO & 5 & 5.88 \\
Total & 12 & 35.48 \\
Jakarta Cempaka Putih Islamic & PIMs & 44 & 6.45 \\
Hospital & & 8 & \\
& PPO & 52 & \\
& Total & &
\end{tabular}

The amount of the risk of the possibility of drug interactions in elderly patients who get 5 9 drugs reaches $50 \%$, while the risk can increase up to $100 \%$ for patients who get more than 20 drugs $^{16}$. A retrospective study on evaluating geriatric inpatient events found that patients who received more than five drugs had almost 4 times the risk of hospitalization due to $\mathrm{ADEs}^{17}$. Other studies stated an increase in the incidence of ADEs that is higher in the elderly than other ages in recent years from 32.7 to 48.8 events with a ratio of 1 in 20 patients $^{18}$. Thus, it can be stated that there is a significant relationship between the increasing number of drugs used with PIMs.

Potentially Inappropriate Medication (PIMs) and Potentially Prescribing Omission (PPO)

Based on the STOPP criteria, from 85 geriatric patients at Gatot Soebroto Army Hospital with 579 drugs used, PIMS was present in $8.24 \%$ of patients with 7 PIMS events, while of 124 patients at Jakarta Cempaka Putih Islamic Hospital with a total of 945 drugs, PIMs were present in $35.48 \%$ of patients with 44 PIMS events (Table II). While based on START criteria, out of a total of 579 
drugs used by geriatric patients at Gatot Soebroto Army Hospital, the prevalence of $\mathrm{PPO}$ was $5.88 \%$. with $5 \mathrm{PPO}$ events and the prevalence of $\mathrm{PPO}$ was $6.45 \%$ with $8 \mathrm{PPO}$ events obtained from 945 drug use at geriatric patients at Jakarta Cempaka Putih Islamic Hospital. The results of this study are higher when compared to studies conducted by Blanco-Reina et al., (2016) that PIMs were present in $18.7 \%$ of patients. The prevalence of PPOs was $34.7 \%$, which is higher than this study. A similar data with this study stated that the prevalence of PIMs were $43.5 \%$ and $40.2 \%$ respectively and the prevalence of $\mathrm{PPO}$ were $52.8 \%$ and $53.9 \%$ respectively ${ }^{20}$.

Potentially Inappropriate Medication (PIMs)

According to STOPP START toolkit supporting medication review version 1 2016, the most common PIMs which found in both hospitals were the combination use of aldosterone antagonist and ACEIs or AIIRA (42.86\% at Gatot Seobroto Army Hospital and $27.27 \%$ at Jakarta Cempaka Putih Islamic Hospital), as seen on table III. The use of a combination of aldosterone antagonists with ACEI or ARB were 12 incidents at Jakarta Cempaka Putih Islamic Hospital and 3 at Gatot Soebroto Army Hospital. These drugs are usually used as antihypertensive therapy which will pose a risk of side effects of hyperkalemia when given in a combination. Symptoms that appear and are very dangerous, especially for geriatrics are bradyarrhythmia, and sudden collapse ${ }^{21}$. The most commonly used combination in this study is spironolactone with candesartan.

The highest number of PIMs were Anticholinergic Drug Burden (ACB score) of $29.55 \%$ in patients at Jakarta Cempaka Putih Islamic Hospital. This scale aims to assess the anticholinergic effect by adding up drugs with anticholinergic effect obtained by the patient. The measurement of Anticholinergic Drug Burden is divided into several categories, they are no anticholinergic activity (value $=0$ ), possible anticholinergic activity (value $=1$ ), definite anticholinergic activity (value $=2$ or 3$)^{22}$. In this study, of 124 patients, 99 patients received drugs with anticholinergic activity and 13 of them included PIMs because the total ACB score was $\geq 4$, while the rest had a total score $<4$. Drugs with anticholinergic activity most often used in this study include alprazolam, ranitidine, furosemide, and betahistine.

Anticholinergic drug prescriptions are usually given for diseases such as depression, parkinsonism, urinary incontinence, peptic ulcer, and allergies ${ }^{23}$. One study reported that the majority of the geriatric population would get at least one type of anticholinergic drug ${ }^{22}$. High-dose anticholinergics with ACB score $\geq 4$ have side effects on nerve disorders, such as delirium, seizures, anxiety, hallucinations, and dementia ${ }^{24}$. It also can reduce cognitive function in geriatrics. However, these side effects are difficult to detect in geriatrics because they are often linked as natural causes that arise during the ageing process ${ }^{23}$. Research conducted in a systematic review showed that of 27 studies only 2 of them did not have an association between anticholinergic use with decreased cognitive function both acute (delirium) and chronic (dementia) ${ }^{25}$.

Potentially Prescribing Omission (PPO)

Based on table IV, the most identified

PPO was the absence of an inhaled corticosteroid drug given to asthma or moderate-severe COPD patients by $75 \%$ in geriatric patients at Jakarta Cempaka Putih Islamic Hospital. The significant number of older asthmatics who are poorly controlled leads to increased morbidity and mortality rate. On the other hand, a clear guidance on asthma management in geriatric asthma patient is minimum. Many geriatric patients who were admitted to emergency departments for asthma condition were not using ICS ${ }^{26}$. This evidence proves the need for inhaled corticosteroid in the elderly. At the Gatot Soebroto Army Hospital, the highest PPO $(60 \%)$ was the absence of or AIIRA (if patient intolerant with ACEI) in diabetes with evidence of renal impairment/disease. Based on the evidence, 
Table III. List of PIMs

\begin{tabular}{|c|c|c|c|}
\hline Location & PIMs criteria & $\mathbf{n}$ & $\%$ \\
\hline \multirow{7}{*}{$\begin{array}{l}\text { Gatot Soebroto } \\
\text { Army Hospital }\end{array}$} & Aldosterone antagonists co-prescribed with ACEIs or & 3 & 42.86 \\
\hline & AIIRA & & \\
\hline & NSAID on moderate-severe heart failure patient & 1 & 14.28 \\
\hline & $\begin{array}{l}\text { Aspirin co-prescribed with clopidogrel as a secondary } \\
\text { stroke prevention }\end{array}$ & 1 & 14.28 \\
\hline & Thiazide diuretic in significant hypokalaemia patient & 1 & 14.28 \\
\hline & Loop diuretic as a single therapy for hypertension & 1 & 14.28 \\
\hline & Total & 7 & 100 \\
\hline $\begin{array}{l}\text { Jakarta } \\
\text { Cempaka }\end{array}$ & $\begin{array}{l}\text { Concomitant use of two or more drugs with potential } \\
\text { for anticholinergic adverse effects (Anticholinergic }\end{array}$ & 13 & 29.55 \\
\hline Putih Islamic & Drug Burden /ACB) & & \\
\hline \multirow[t]{14}{*}{ Hospital } & $\begin{array}{l}\text { Aldosterone antagonists co-prescribed with ACEIs or } \\
\text { AIIRA }\end{array}$ & 12 & 27.27 \\
\hline & $\begin{array}{l}\text { Sulfonylureas with a long duration of action with type } \\
2 \text { diabetes mellitus }\end{array}$ & 3 & 6.82 \\
\hline & Centrally-acting antihypertensives use on elderly & 3 & 6.82 \\
\hline & NSAID with severe or uncontrolled hypertension & 2 & 4.55 \\
\hline & $\begin{array}{l}\text { Diuretics which increase urinary flow with concurrent } \\
\text { urinary incontinence }\end{array}$ & 2 & 4.55 \\
\hline & $\begin{array}{l}\text { Alpha1-receptor blocker in those with symptomatic } \\
\text { orthostatic hypotension }\end{array}$ & 2 & 4.55 \\
\hline & Domperidone in patients with serious heart conditions & 1 & 2.27 \\
\hline & ACEIs or AIIRA in patients with hyperkalaemia & 1 & 2.27 \\
\hline & $\begin{array}{l}\text { Amiodarone as first-line therapy for arrhythmia in } \\
\text { supraventricular tachyarrhythmias }\end{array}$ & 1 & 2.27 \\
\hline & $\begin{array}{l}\text { Benzodiazepines on patient who had fallen in the past } \\
3 \text { months }\end{array}$ & 1 & 2.27 \\
\hline & Loop diuretic as a single therapy for hypertension & 1 & 2.27 \\
\hline & $\begin{array}{l}\text { Loperamide on patient with blood and mucus in the } \\
\text { stools }\end{array}$ & 1 & 2.27 \\
\hline & Verapamil with heart failure & 1 & 2.27 \\
\hline & Total & 44 & 100 \\
\hline
\end{tabular}

the provision of combination therapy with ACE Inhibitors or AIIRA could inhibit the development of renal disease ${ }^{1}$.

Correlations between Patient Characteristics and PIMs

Based on Pearson's chi-squared test in table $\mathrm{V}$, there was no statistically significant association between sex or age and PIMs in both hospitals. This is supported by research which states that age, sex, multiple diseases, and the use of $\leq 4$ medications was not related to PIMs prescription ${ }^{27}$. Meanwhile, the results of the correlation test between the number of drugs with the incidence of PIMs in geriatric patients showed a significant relationship $(\mathrm{p}$-value $=0.013)$ in patients at Jakarta Cempaka Putih Islamic Hospital. Polypharmacy was an independent predictor of PIMs.

There are some efforts that can be done to prevent the incidence of PIMs in both hospitals, considering the conditions of both hospitals. The first attempt is to use the STOPP 
Table IV. List of PPO

\begin{tabular}{clcc}
\hline Location & \multicolumn{1}{c}{ PPO Criteria } & $n$ & \% \\
\hline $\begin{array}{c}\text { Gatot } \\
\text { Soebroto } \\
\text { Army }\end{array}$ & $\begin{array}{l}\text { ACEI or AIIRA (if intolerant of ACEI) in diabetes patient } \\
\text { with evidence of renal disease }\end{array}$ & 3 & 60 \\
Hospital & Appropriate beta-blocker with stable systolic heart failure. & 1 & 20 \\
& $\begin{array}{l}\text { Regular inhaled Beta-2 agonist for mild to moderate } \\
\text { COPD. }\end{array}$ & 1 & 20 \\
& $\begin{array}{l}\text { Total } \\
\text { Regular inhaled corticosteroid for moderate-severe } \\
\text { asthma or COPD }\end{array}$ & $\mathbf{5}$ & $\mathbf{1 0 0}$ \\
Jakarta & & 75 \\
$\begin{array}{c}\text { Cempaka } \\
\text { Hospital }\end{array}$ & $\begin{array}{l}\text { ACEI or AIIRA (if intolerant of ACEI) in diabetes with } \\
\text { evidence of renal disease }\end{array}$ & 1 & 12.5 \\
& $\begin{array}{l}\text { Vitamin D and calcium (where dietary calcium intake } \\
\text { inadequate) supplement in patients with known } \\
\text { osteoporosis } \\
\text { Total }\end{array}$ & 1 & 12.5 \\
& & $\mathbf{8}$ & $\mathbf{1 0 0}$ \\
\hline
\end{tabular}

Table V. Correlation between Patient Characteristics and PIMs

\begin{tabular}{clc}
\hline Location & Correlation & P-value \\
\hline Gatot Soebroto Army Hospital & Sex*PIMs & 0.213 \\
& Age*PIMs & 0.922 \\
& The number of medicines *PIMs & 0.050 \\
& & \\
Jakarta Cempaka Putih Islamic & Sex*PIMs & 0.651 \\
Hospital & Age*PIMs & 0.790 \\
& The number of medicines *PIMs & $\mathbf{0 . 0 1 3}$ \\
\hline
\end{tabular}

and START criteria or to make another standard or guideline specialized on each hospital to guide doctors when choosing treatment for patients, this also require some laboratory data needed to make sure that the treatment given is suitable for patients, including for PPO. The second one is to strengthen pharmacist role on screening the patient's prescription. Pharmacist should be alert when patients get more than 5 drugs, since there is a significant relationship between the increasing number of drugs used with PIMs. Pharmacist should also be aware when patients prescribed with drugs with anticholinergic activity.
This study still has many limitations. As only 2 hospitals were involved in this study, result generalization for the Indonesian geriatric population is very limited.

\section{CONCLUSION}

The prevalence of PIMs in the study was considerably moderate $(8.24 \%$ and $35.48 \%)$ while the prevalence of PPO was $5.88 \%$ and $6.45 \%$, respectively. There is a significant correlation between the number of drugs with the incidence of PIMs. Health care professionals are expected to be able to review medication prescribed for geriatric patients 
using new guidelines so that the incidence of PIM can be prevented.

\section{ACKNOWLEDGEMENT}

The authors acknowledge LEMLITBANG UHAMKA who has funded this research and all pharmacist and other health professions at Gatot Soebroto Army Hospital and Jakarta Cempaka Putih Islamic Hospital that involved in this research.

\section{REFERENCES}

1. Dipiro JT, Talbert RL, Yee GC, Matzke GR, Wells BG, Posey LM. Pharmacotherapy: A Pathophysiologic Approach.; 2017.

2. World Health Organization. Ageing and Health. 2018;(February 2018):1-4.

3. Ministry of Health Republic of Indonesia. Peraturan Menteri Kesehatan RI No. 79 Tahun 2014 tentang Penyelenggaraan Pelayanan Geriatri di Rumah Sakit. Indonesia. 2014:1-36.

4. Ministry of Health Republic of Indonesia. Situasi Lansia di Indonesia Tahun 2017. 2017.

5. Momin TG, Pandya RN, Rana DA, Patel VJ. Use of potentially inappropriate medications in hospitalized elderly at a teaching hospital: A comparison between Beers 2003 and 2012 criteria. Indian J Pharmacol. 2013;45(6):603.

6. O'Mahony D, Gallagher P, Ryan C, et al., STOPP \& START criteria: A new approach to detecting potentially inappropriate prescribing in old age. Eur Geriatr Med. 2010;1(1):45-51.

7. Rosa ASKC da, Costa BP, Kapper CP, et al., Identification of inappropiate prescribing in a Geriatric outpatient clinic using the Criteria Stopp Start. Rev Bras Geriatr e Gerontol. 2016;19(5):871-879.

8. Pyszka LL, Seys Ranola TM, Milhans SM. Identification of inappropriate prescribing in geriatrics at a veterans affairs hospital using STOPP/START screening tools. Consult Pharm.
2010;25(6):365-373.

9. Muhte G, Yayla E, Bilge UL, Binen E, Keskin A. The Use of START / STOPP Criteria for Elderly Patients in Primary Care. Sci World J. 2013;2013.

10. Mulyani E, Darmawan E, Mustofa M. Hubungan Jumlah Obat Yang Diresepkan Dengan Potensial Penggunaan Obat Yang Tidak Tepat Pada Pasien Ckd Di Rs Pku Muhammadiyah Yogyakarta. Pharmaciana. 2015;5(2):153.

11. Syuaib ANM, Dermawan E, Mustofa. Penggunaan Potentially Inappropriate Medications (PIMs) pada Pasien Geriatri Rawat Inap Osteoarthritis di RS PKU Muhammadiyah Yogyakarta. Pharmaciana. 2015;5:77-84.

12. United Nations, Department of Economic and Social Affairs, Population Division. World Population Ageing $2017 \quad$ - Highlights (ST/ESA/SER.A/397); 2017. http://www.un.org/en/development/ desa/population/publications/pdf/age ing/WPA2017_Highlights.pdf.

13. Davies EA, O'Mahony MS. Adverse drug reactions in special populations The elderly. $\mathrm{Br} \mathrm{J}$ Clin Pharmacol. 2015;80(4):796-807.

14. Neto PRO, Nobili A, de Lyra DP, et al., Incidence and predictors of adverse drug reactions caused by drug-drug interactions in elderly outpatients: A prospective cohort study. I Pharm Pharm Sci. 2012;15(2):332-343.

15. Shah BM, Hajjar ER. Polypharmacy, Adverse Drug Reactions, and Geriatric Syndromes. Clin Geriatr Med. 2012;28(2):173-186.

16. Doan J, Zakrzewski-Jakubiak H, Roy J, Turgeon J, Tannenbaum C. Prevalence and Risk of Potential Cytochrome P450-Mediated Drug-Drug Interactions in Older Hospitalized Patients with Polypharmacy. Ann Pharmacother. 2013;47(3):324-332.

17. Marcum ZA, Amuan ME, Hanlon JT, 
et al., Prevalence of unplanned hospitalizations caused by adverse drug reactions in older veterans. $J \mathrm{Am}$ Geriatr Soc. 2012;60(1):34-41.

18. Bourgeois FT, Shannon MW, Valim C, Mandl KD. Adverse Drug Events in the Outpatient Setting: an 11-year national analysis. Pharmacoepidemiol Drug Saf. 2010;19(July):901-910.

19. Blanco-Reina E, García-Merino MR, Ocaña-Riola $\mathrm{R}$, et al., Assessing Potentially Inappropriate Prescribing in Community-Dwelling Older Patients Using the Updated Version of STOPPSTART Criteria: A Comparison of Profiles and Prevalences with Respect to the Original Version. PLoS One. 2016;11(12):e01:1-10.

20. Chandrasekhar D, Samjas M. Evaluation of potentially inappropriate medications among hospitalized geriatric patients in tertiary care referral hospital using STOPP / START criteria. Clin Epidemiol Glob Heal. 2018;(January):0-1.

21. American Heart Association. What Is Hyperkalemia ( High Potassium )? 2017.

22. Fox C, Richardson K, Maidment ID, et al., Anticholinergic medication use and cognitive impairment in the older population: The medical research council cognitive function and ageing study. $J \mathrm{Am}$ Geriatr Soc. 2011;59(8):1477-1483.

23. Kersten H, Wyller TB. Anticholinergic Drug Burden in Older People's Brain How well is it Measured? Basic Clin Pharmacol Toxicol. 2014;114(2):151-159.

24. Markov YI. Anticholinergic syndrome (lecture). Emerg Med. 2017;0(1.80):1720.

25. Campbell N, Boustani M, Limbil T, et al., The cognitive impact of anticholinergics: a clinical review. Clin Interv Aging. 2009;4:225-233.

26. Melani AS. Management of asthma in the elderly patient. Clin Interv Aging. 2013;8:913-922.

27. Abdulah $\mathrm{R}$, Insani WN, Destiani DP, Rohmaniasari N, Mohenathas ND, Barliana MI. Polypharmacy leads to increased prevalence of potentially inappropriate medication in the indonesian geriatric population visiting primary care facilities. Ther Clin Risk Manag. 2018;14:1591-1597. 